\title{
The Impact of Market Environments on Marketing Relationships
}

\author{
Roger R. Betancourt ${ }^{1}$, Raquel Chocarro ${ }^{2}$, Monica Cortiñas ${ }^{2}$, Margarita Elorz ${ }^{2} \&$ Jose Miguel Mugica $^{2}$ \\ ${ }^{1}$ Economics Department, University of Maryland, USA \\ ${ }^{2}$ BussinessManagent Department, Universidad Publica de Navarra, Navarra, Spain \\ Correspondence: Roger R. Betancourt, Economics Department, University of Maryland, College Park, MD \\ 20742, USA. Tel: 1-301-405-3479. E-mail: betancou@econ.umd.edu
}

Received: March 5, 2013 Accepted: September 30, 2013 Online Published: January 22, 2014

doi:10.5539/ijms.v6n1p45 URL: http://dx.doi.org/10.5539/ijms.v6n1p45

\begin{abstract}
This paper addresses empirically two issues. One is whether or not basic marketing relationships at the establishment level are robust to a substantial change in the market environment. Another one is whether after this event takes place the marketing relationships for new establishments are the same as those for existing establishments. We rely on two data sets: a survey of gas stations in 1998 in Pamplona, Spain, when prices of gasoline products were fixed by the government; and a similar survey in 2007, when gas retail prices were determined by market participants as a result of the price liberalization law. Briefly put, customer satisfaction and its determinants have a robust, stable relationship with respect to the law's change in market environment during this nine year period. On the other hand, some aspects of the relation between future patronage intentions and its determinants are substantially altered by the law's change in market environment.
\end{abstract}

Keywords: retailing, customer satisfaction, gas stations, future patronage intentions, one timeevents, stable relationships

\section{Introduction}

One difficulty in analyzing the impact of one time events on behavioral relationships in any field is that they are usually accompanied by other changes at the same time. Nonetheless, if one observes two comparable situations, one in which the one time event took place and one in which it did not, it becomes possible to argue that a natural experiment took place through two comparisons: before and after the one time event took place in each of the two situations. This feature underlies the application of the difference in differences approach to these so-called natural experiments. The focus of these approaches has been on establishing causality. What has been neglected in many of these applications is that one time events can also shed light on the stability or robustness of behavioral relationships regardless of the presence of the two comparable situations or, perhaps more importantly, of how comparable the before and after situations are.

Any one time event generates two possible outcomes on behavioral relationships. Either one observes no changes in the behavioral relationships of interest after the event or one observes changes in these relationships. In the former case, it is very unlikely that the event had an effect on these relationships or that everything else in the market environment changed in just the right way to offset the changes induced by the event. Thus, the argument that the event had no effect is usually convincing in and of itself. In the latter case, however, any observed change may also be due to the other things that were changing at the same time. Hence, it is difficult to establish causality solely based on this evidence, i.e., that the change was due to the event. Indeed, the recent econometric literature focuses on addressing the difficulties of concluding that a change was due to an event even in the presence of two seemingly comparable situations (Imbens \& Wooldridge, 2009). Since evidence of inter-temporal stability or of no change in a relationship is of significance in any scientific endeavor and it is a question we can answer convincingly, we concentrate on this issue in our first study. The latter entails a comparison of two different behavioral relationships for the same establishments before and after the event.

The substantive setting of our analysis is a retail service industry, namely gas stations in the Spanish city of Pamplona. We focus on two well established and related marketing relationships: customer satisfaction and its determinants as well as future patronage intentions and its determinants. The one time event that is at the center of our analysis is the passage of a law in 1998 liberalizing gas retail prices in Spain (Bello \& Cavero, 2008). The main macroeconomic events that would have affected these relationships after passage of the law are those 
associated with the rapid growth of the Spanish economy: Namely, substantial increases in per capita income and associated changes due to this period coinciding with the expansion phase of the business cycle. The latter is identified as taking place from 1995-2006 by the Spanish central bank (Banco de España, 2008).

In our second study we compare new and existing establishments after the passage of the law. If these two basic marketing relationships are the same for both types of establishments after the passage of the law, it reinforces the results of the first study for those aspects of the relationships that did not change after the passage of the law. If they differ, it raises the question of whether or not we can identify market level changes that can explain how the two types of establishments adjust to the law and associated macroeconomic changes. Our data allow us to identify important elements on the demand side and on the supply side that are likely sources of these differences in Pamplonas's market. They are consistent with a nationwide increase inthe number of gas stations from 8,000 in 1998 to 8,974 in 2007 where most of the increase had been achieved by 2001 (Memoria AOP 2007, www.aop.es).

Customer satisfaction is usually viewed as a means to an end and the end can be an economic performance variable other than future patronage intentions. These have included, for example, the rate of return on investment (Anderson, Fornell, \& Lehman, 1994) and Tobin's q (Anderson, Fornell, \& Mazvancheryl, 2004). More recent literature has extended the possibilities by considering its effect on other outcomes viewed as intervening variables, for example advertising or efficiency (Luo \& Homburg, 2007). This enhances the importance of our results for customer satisfaction, since they can be relevant for many settings. On the other hand, it generates a wide array of potential specifications on how product price affects outcomes of interest to retailers. Our investigation is pertinent for all model specifications that include a direct effect for product price on customer satisfaction whether or not there is an additional separate effect on the performance or intervening variable of interest.

We discuss prior literature on both marketing relationships and on the conceptual basis for the empirical specifications adopted in the next section. Subsequently, we discuss the main macroeconomic events and the two data sets relied upon for our analysis. The latter section sets the stage for a discussion of empirical implementation and the estimation procedure. To keep the paper of manageable length an appendix available on the web provides additional details on the data. For simplicity of exposition we present the results as follows: first, we address the issue of inter-temporal stability or robustness of the two relationships; and, second we address the issue of similarity and differences in these marketing relationships between new and existing establishments. We conclude with a brief summary of contributions, implications and limitations.

\section{Brief Review of Literature on Relevant Marketing Relationships and Conceptual Framework}

In marketing a standard framework for the analysis of customer satisfaction has developed from a frequently cited paper (Anderson \& Sullivan, 1993). Within the context of manufacturing this framework has been extended in a number of directions (e.g., Kopalle \& Lehmann, 2006). Contributions in the context of the service sector have proceeded by treating "...service quality and customer satisfaction almost interchangeably" (Rust \& Zahorik, 1993), or by using attributes to identify service quality or customer satisfaction (Gomez, McLaughlin, \& Wittink, 2004; Malthouse et al., 2004). These attributes correspond to the distribution services stressed in economics and marketing (Bucklin, 1978; Betancourt \& Gautschi, 1988; Oi, 1992; Berry, Seiders, \& Grewal, 2002; Betancourt, 2004). More recently, an approach that integrates the framework previously applied to manufacturing with attributes of the distribution sector has been applied to supermarkets (Betancourt et al., 2007).

Relaxing the assumption that the demand for these services equals the supply of these services allows application of the same conceptual approach to customer satisfaction with products of manufacturing to their satisfaction with services of establishments in the retail sector. Furthermore, under the same assumptions made in previous empirical analyses of the retail sector (i.e., the use of a standard of pleasure or displeasure as argued by Oliver, 1999), this integration is suitable for empirical implementation with typically available survey data.

In this approach customer satisfaction is inversely related to the gap between customer's i demand for distribution services and his/her perception of the supply of distribution services provided by establishment $\mathrm{k}$. That is, Dd (i)-Ds (i, k), where D is a vector of distribution services that corresponds to various attributes of the establishment or firm. These distribution services will be indexed by $\mathrm{j}$. Characteristics of customers that patronize an establishment other than their perceptions of attributes or distribution services $(\mathrm{X}(\mathrm{i}, \mathrm{k})$ ), but including their perceptions of price, and objective characteristics of establishments (X (k, k)), can also affect customer satisfaction. They correspond to the three types of variables used in the retail literature as the main determinants of customer satisfaction. 
Following the empirical literature on customer satisfaction in retailing, we will assume that customers' demand for a distribution service, $\mathrm{j}$, is never satisfied and is always at its maximum, $\mathrm{M}$, which is the same for all consumers. Thus, consumer i satisfaction with a gas station, $\mathrm{k}$, can be described by a relation of the following form

$$
S_{i}(k)=f\left\{\left[M-D^{s}(i, k)\right]_{j}, X(i, k), X(k, k)\right\}
$$

where $S_{i}(k)$ is a measure of customer satisfaction. In (1) satisfaction is viewed as a decreasing function, $f_{j}^{\prime}<0$, of the distance between each of the $\mathrm{j}$ distribution services actually provided by station $\mathrm{k}, \mathrm{D}^{\mathrm{s}}(\mathrm{i}, \mathrm{k})$, as perceived by the consumer, and the maximum level of each of the $\mathrm{j}$ distribution services demanded by consumer $\mathrm{i}$, M. This specification allows us to address our basic questions. Does the passage of the law and associated macroeconomic events change the relationship between customer satisfaction and its determinants? Is the relationship between customer satisfaction and its determinants the same for existing establishments and new establishments?

The literature on the impact of customer satisfaction on economic performance variables stresses the links between attributes or distribution services, customer satisfaction and economic performance variables. Initially profitability was used as the relevant performance variable (e.g., Anderson \& Mittal, 2000; Kamakura et al., 2002), but future patronage intentions has also been used as a relevant performance variable (e.g., Rust \& Zahoric, 1993; Grace \& O'Cass, 2005). The latter is the relevant performance variable for our purposes since it is the one available in our data. Nonetheless we draw from both strands of literature in specifying the second link given by equation (2) below. The first link is, of course, given by equation (1).

Future patronage intentions, $\mathrm{P}(\mathrm{i}, \mathrm{k})$, by a consumer, i, with respect to an establishment, $\mathrm{k}$, are determined as a function of customer satisfaction, $\mathrm{Si}(\mathrm{k})$, and a set of controls capturing characteristics of consumers that patronize an establishment $(\mathrm{Z}(\mathrm{i}, \mathrm{k}))$, including perceptions of prices charged by the establishment, and objective characteristics of the establishments $(Z(k, k))$. These capture the main types of variables used in the retail literature as determinants of or direct effects on future patronage intentions. Thus we address the same basic questions about future patronage intentions as we do for customer satisfaction with the following specification

$$
P(i, k)=h[S i(k), Z(i, k), Z(k, k)]
$$

A recent overview paper on retailer pricing and competitive effects (Kopalle et al., 2009) states “...a key component of the output of retailing is a set of services..." It goes on to add that the latter provide benefits to consumers and affect their willingness to pay for the explicit products sold by retailers. Thus, the first and perhaps most important element of the customer satisfaction relationship we will address is the inter-temporal stability of these services in determining satisfaction with gas stations. Similarly, in the case of future patronage intentions we will focus first on the inter-temporal stability of the effect of customer satisfaction. In both marketing relationships these variables are usually the ones directly subject to managerial control at the establishment level.

One standard practice in the literature on customer satisfaction is to control for characteristics of consumers, including their perception of prices of a product or set of products, that may affect customer satisfaction with an establishment. Thus, the second element of the relationship we will address is the inter-temporal stability of customer characteristics in determining customer satisfaction. We will do the same for the determinants of future patronage intentions.

Finally, an issue that has not been pursued as systematically in the literature on customer satisfaction in retailing is the extent to which objective characteristics of the establishment, and in particular it's competitive environment, have a direct effect on customer satisfaction. We will address the inter-temporal stability of these objective characteristics in determining satisfaction. By contrast and not surprisingly, objective characteristics of establishments have received attention in the future patronage intentions literature (e.g., Sirohi et al., 1998; Seiders et al., 2005). Thus, we will also investigate the inter-temporal stability of this third element of the relationship for future patronage intentions.

More generally, we will pursue the same approach in our second study. That is we will ask whether the relationship between customer satisfaction (future patronage intentions) and its determinants is the same for new and existing establishments in terms of these same three basic elements of the relationships. Finally, we summarize the discussion of the conceptual framework presented here with the following figure. 


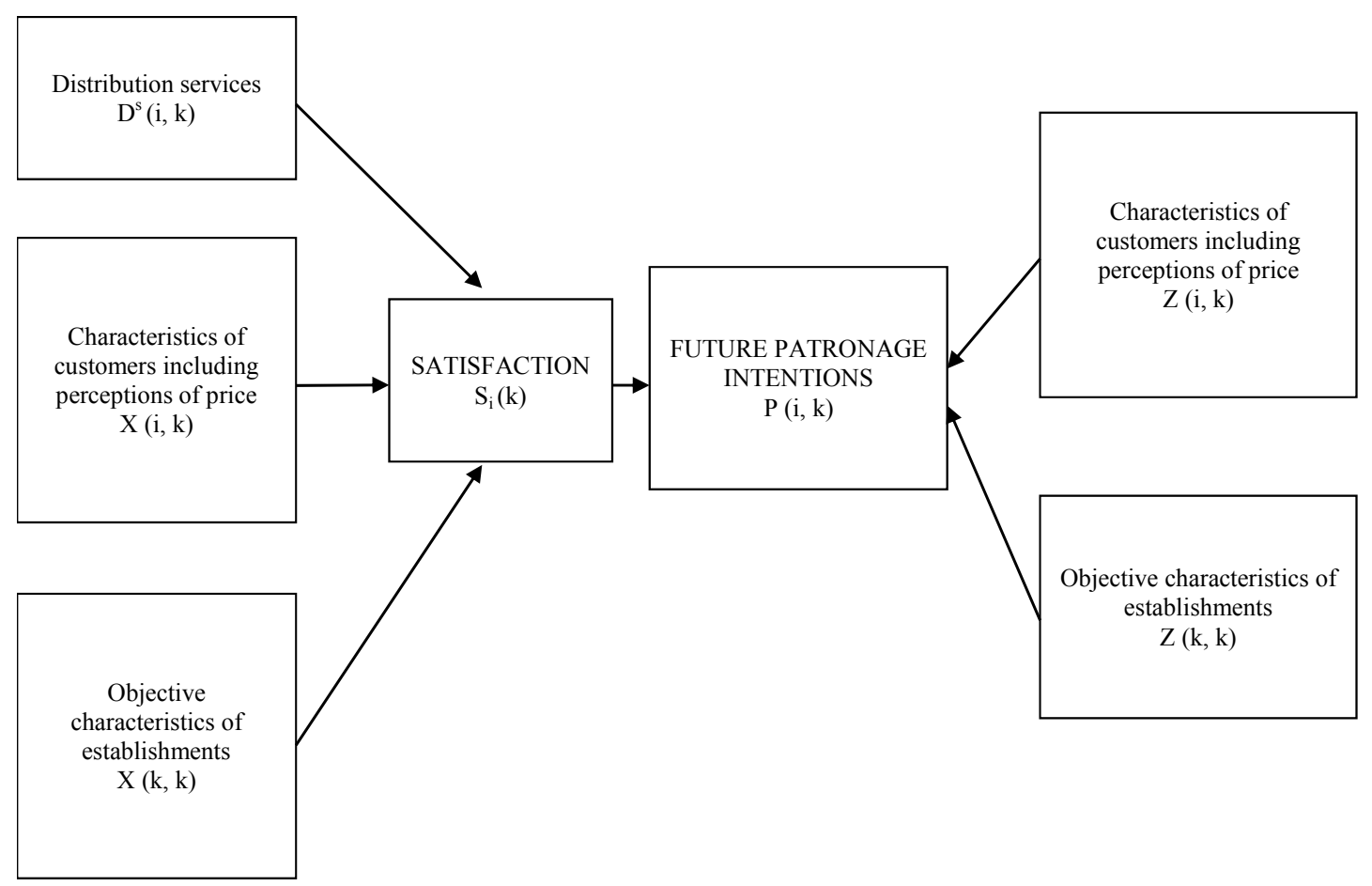

Figure 1. Conceptual framework

\section{Macroeconomic Setting and Data}

The price liberalization process at the retail level is part of the evolution of the petroleum industry in Spain. The Spanish gasoline market was highly regulated for many years (Correljé, 1990). Various aspects of an opening transition process started as early as the mid 1980's and accelerated in the 1990's (Contín, Correljé, \& Huerta, 1999), at about the same time as in some other countries (Clements, Jung, \& Gupta, 2007). Small regional differences in retail prices (less than 1\% at the province level), however, only begin to appear in 1998 after the law liberalizing gas retail prices was passed on October 7 1998, effective the following day. In the spring of 1998, before this law was passed, we undertook a survey of consumers regarding their satisfaction with gas stations and future patronage intentions in Pamplona.

Since 1998 noticeable differences in prices have appeared within the city. For instance, in the spring of 2007 observed differences in prices at gas stations within Pamplona's beltway ranged from 5\% for unleaded premium to $7 \%$ for diesel. We undertook a survey of gas stations in Pamplona in the spring of 2007 to ascertain consumer satisfaction with gas stations as well as its effect on future patronage intentions in this new liberalized environment. This survey, in combination with the earlier one, provides an unusual opportunity to examine the inter-temporal stability of these marketing relationships as well as the similarities and differences in how they apply to new and existing establishments.

Many changes were taking place in Spain between 1998 and 2007. In particular, this period was one of great prosperity for the Spanish economy and Navarra shared in this prosperity. Pamplona is Navarra's largest city. For instance, according to InstitutoNacional de Estadística during this period the rate of growth of GDP in Spain was $3.8 \%$ whereas in Navarra it was $3.7 \%$. Similarly, unemployment in Spain decreased by $14 \%$ between 1995 and 2006 (Bentolila, Dolabo, \& Jimeno, 2008) while in Navarra it decreased by almost 18\% between 1998 and 2007. This nine year gap has two effects on our analysis. First, it accentuates the need to concentrate on identifying inter-temporal stability or those aspects of these marketing relationships that are not affected by the passage of the law and the associated macroeconomic changes. Both the effects of the law and the macroeconomic changes had ample time to affect the behavioral relationships in nine years. Second, it suggests the need to differentiate between new and existing establishments. For, nine years is plenty of time for market entry (and exit) to take place and for this change in the competitive aspects of the market environment to affect the nature of the marketing relationships in both types of establishments. As a matter of fact, eight of the 24 stations within Pamplona's beltway were built during these nine years. 
Our 1998 data set consists of surveys of customers at eight gasoline stations in Pamplona. Consumers were selected for interviews upon arrival at the gas station during one week in the spring of 1998. The survey was designed over a period of a month. The interviewers were trained in one meeting; their instructions were printed in the first page of the survey; and they were asked to fill the surveys themselves. Five interviewers were assigned to each station, spaced over the day, each day of the week. These surveys generated a total of 280 observations with a maximum number of 41 interviews at one station and a minimum number of 21 at another. Eliminating the station that went out of business by 2007 reduces the overall sample of observations in 1998 by 29 observations, leaving us with 251 observations.

By contrast, our 2007 data set consists of surveys of customers at the seven gasoline stations from 1998 that survived the passage of the law AND eight additional ones that were surveyed only in 2007. At the time of the 1998 survey the seven surviving stations were $41.2 \%$ of the universe of gas stations within Pamplona's beltway. The total of 15 stations surveyed in 2007 represent $62.5 \%$ of the universe of gas stations within Pamplona's beltway.

Consumers were selected for interviews upon arrival at the gas station during the spring of 2007 when the survey took place. This survey was designed as a slightly modified version of the one used in 1998. In terms of the questionnaire: we added two entirely new questions; we split two old questions into two components; and we eliminated an earlier one completely. See the Data Appendix. Just as before, the interviewers were trained in one meeting, their instructions were printed in the first page of the survey, and they were asked to fill the surveys themselves. In contrast to the 1998 survey, however, two interviewers were assigned to each station and the interviews were spaced over the day but over two weeks. The interview process was designed to generate 40 interviews for each station over the two weeks period. There is a maximum number of interviews of 40 at five stations and a minimum number of 33 at one station.

Two factors led to differences in the interview process between the two survey years. First, in 1998 the interviewers were not asked to keep an explicit record of the response rate but to give an overall assessment. The latter were reported to be between $40 \%$ and $50 \%$. Survey experts at our institution in Pamplona view this response rate as typical for surveys of this nature. They are well within the range of those reported in the literature for comparable surveys (Baruch, 1999; Yu \& Cooper, 1983). Nevertheless, in 2007 we decided to try to have an explicit record. Interviewers were asked to indicate the number of refusals between interviews in order to obtain a more accurate estimate of the response rate. We also had fewer different interviewers per station than in 1998 to reduce possible variability in responses due to variations in interviewer characteristics.

In 2007 there were 289 refusals between interviews over the 15 stations. The estimated response rate for these stations was $67.5 \%$. These percentages are upper bounds on the response rate. After eliminating those that failed to answer more than three questions we had 265 observations over the seven stations also sampled in the 1998 survey and 570 observations over the 15 stations sampled in 2007.

Supplementing the survey data, we also gathered information on objective characteristics of the gas stations. One set of these measures tried to capture competitive conditions facing each establishment. A second set of these measures tried to capture objective conditions of the gas stations that could affect customer satisfaction or future patronage intentions. They are also described in detail in the Data Appendix. Most of the information on these variables was gathered in both 1998 and 2007 since interviewers were asked to record objective characteristics of the station in both years.

\section{Empirical Implementation}

From the data described above we constructed two different data sets to use in our empirical analysis. For use in study 1 we put together the data gathered for the seven stations that existed in 1998 and that were also surveyed in 2007. Thus, we had the same seven gas stations in the same location in both years. We also examined the data gathered on the objective characteristics of these stations to see if there had been major changes that would lead these stations to be substantially different in both years. While there were some changes in two cases, we would not call them major. In one case the change allowed an increase in the number of cars that could be handled by the station simultaneously from 8 to 9 ; in the other case, it allowed a decrease in the number of cars that could be handled by the station simultaneously from 10 to 8 .

For use in study 2 we put together the data for all of the 15 gasoline stations that were surveyed in 2007. Among these 15 stations there were 4 that did not exist in 1998. They were new and were able to choose their location, layout and equipment after the passage of the law in 1998. Thus, the data set used in study 2 consisted of 11 stations existing in 1998 and four new stations built after the passage of the law in 1998. 
Both outcome variables of interest were measured on the same scale in the 1998 and the 2007 surveys. Si (k) represents consumer's i satisfaction with station $\mathrm{k}$ or the dependent variable in equation (1). It was measured as the answer to the following question, on a scale of $0-10$. - What is your degree of satisfaction with the services provided and the purchases made at this station? $\mathrm{P}(\mathrm{i}, \mathrm{k})$ represents future patronage intentions or the dependent variable in equation (2). It was measured as the answer to the following question, also on a scale zero to10. Will you put gas in this station in the future? These measurements were the same in study 1 and in study 2 .

In the analysis of customer satisfaction, there are three types of variables used as explanatory variables or direct effects. One type is referred to as distribution services or simply services or attributes of establishments as perceived by consumers. A second type is consumer characteristics in which we will include their perception of the prices of the products offered by the establishment relative to other establishments of the same type. A final one is objective characteristics of the establishment. In the analysis of future patronage intentions we can also classify the explanatory variables into three types: customer satisfaction; customer characteristics (other than satisfaction of course), and objective characteristics of the establishment. Thus, we will discuss below distribution services, customer characteristics and objective characteristics of the establishment. Customer satisfaction has already been defined above in the context of its use as a dependent variable.

Distribution services have been assigned to one of the following five broad categories by the sources cited earlier: accessibility of location, information, assortment, assurance of product delivery, and ambience. Measurement of these five services at the level of the establishment has been undertaken for supermarkets (Betancourt et al., 2007) and hardware stores (Barber \& Tietje, 2004). We followed their procedures with minor changes to adapt them to the context of gas stations. The details of the adaptation are available in the Data Appendix posted on the web.

Consumers were asked to rate on a scale of $0-10$ a number of attributes that corresponded to (or at least correspond to an explicit dimension of) the five distributions services identified above. Given that the maximum in the measurement scale for these services was a 10 , we introduced these services in the customer satisfaction equation as [10-D (i, k)j]. Notice that an increase in [10-D (i, k)j] implies a lowering of the level of the jth distribution service as perceived by the consumer. Hence, it should result in a lower level of customer satisfaction because the distance between the quality or level of service offered and the one expected has increased. That is, we expect a negative or at least non-positive sign for each of these five variables in equation (1). In general these variables are subject to managerial control.

By contrast the next set of variables refers to customer characteristics that are not subject to managerial control with one important exception. That is demographics and customer buying habits are not generally viewed as subject to managerial control. Customers perceptions of prices of products are (e.g., Briesch, Krishnamurthi, Mazumdar, \& Raj, 1997). We have included them in this second type for two reasons. First, given our focus on the passage of a law allowing prices to be set by market participants, they merited special attention and it facilitated the exposition to treat them in this group. Second, prices and their perceptions are frequently viewed as distinct from services because the latter are not explicitly priced in most circumstances.

General demographic characteristics of consumers were included as controls, although we had no expectations as to how or if they would affect customer satisfaction or patronage intentions in terms of their signs. In particular we obtained and used information on: gender, X7; age, X8; position in the life cycle, X9; and extent of work outside the home, X10. We also included a variable that captured on a scale of 0-10 whether consumer perceptions of prices at the establishment relative to other establishments were high, X6.

Similarly, four objective and three subjective characteristics of customers buying habits were used in various versions of the empirical analysis. The four objective ones were: the length of stay at the station, X11, the size of the average purchase at the station, $\mathrm{X} 12$, the frequency of gasoline purchases at the station, $\mathrm{X} 13 \mathrm{~B}$, and the inter-purchase time of gasoline in days, X13A. The three subjective ones reflect attitudes toward purchasing gasoline products. They were: preferences toward pumping your own gasoline, X14; the importance of reducing time spent on this activity, X15; and, inclination to search for alternative stations when making this type of purchase, X16.

The third type of variables included resulted from our gathering data on a variety of objective characteristics of gas stations that could help identify important changes between 1998 and 2007 as well as differences between stations more generally. The main one relating to competitive aspects was, for example, the number of gas stations within 5 kilometers of each of the gas stations in the sample (O6). With respect to objective conditions of the gas station itself we considered, for example, whether or not self-service was available (O1), the number of cars that could be serviced simultaneously by the combination of hoses, pumps and aisles available at the station $(\mathrm{O} 2)$, displays of information on prices $(\mathrm{O} 3)$, number of aisles $(\mathrm{O} 4)$, and the price of diesel (O5). Note 
that these variables only vary across stations (at most 14 in study 1 and 15 in study 2).

In the Data Appendix available on the web these objective variables are described in greater detail. There we also describe the procedure used to convert the two variables measured in monetary terms (X12 and O5) into the same units, 2007 euros. In the paper itself we include a Statistical Appendix with two tables of descriptive statistics that provide means, standard deviations, maxima and minima for all the variables mentioned in this section. These tables also include differences in the means between years for study 1 and between existing and new stations for study 2 as well as the t-ratio of a test of these differences for all these variables.

For estimation purposes we want to ascertain the effects of allowing gasoline retail prices to be determined by market participants after the passage of the law on the relationship between the explanatory variables (which we will label $X^{*}$ to capture the ones used in either equation (1) or equation (2)) and the dependent variable (which we will label $\mathrm{Y}$ to capture the dependent variable in either one of the two equations to be estimated). A simple exposition of the basic considerations underlying the procedure we will follow in both study 1 and study 2 is available (e.g., Gujarati, 1970; Greene, 2007).

We can write our estimation equation as

$$
Y=\beta X^{*}+\delta D X^{*}+U
$$

where $\mathrm{Y}$ is a column vector of all i observations on a dependent variable. In study 1 the 1998 ones are 'stacked up' below the 2007 ones. In study 2 the existing ones are stacked up below the new ones. $\mathrm{X}^{*}$ is a matrix of independent variables with $\mathrm{K}+1$ columns of explanatory variables 'stacked' up in the same fashion as $\mathrm{Y}$. By convention we will assume the first column to be a vector of 1's, which yields the standard intercept in a regression. $\mathrm{D}$ is a dummy variable that takes on the value of 1 if an observation belongs to the 2007 sample (study 1) or to a new station (study 2) and zero otherwise. $U$ is a column vector of disturbance terms associated with each observation similarly 'stacked up'. Greek letters indicate parameters to be estimated. Given our formulation of the dummy variable, the standard parameters $(\beta)$ in study 1 correspond to 1998 whereas the parameters associated with the dummy $(\delta)$ are the difference between any parameter in 2007 and 1998 . That is, $\delta$ $=\beta$ (2007) $-\beta$ (1998). Similarly, the standard parameters $(\beta)$ in study 2 correspond to the existing stations whereas the parameters associated with the dummy $(\delta)$ are the difference between any parameters for the new ones and the existing ones. That is, $\delta=\beta$ (new) - $\beta$ (existing).

In general the market determination of gasoline retail prices allowed by the law and the other changes associated with these nine years can have at least two consequences that affect the determinants of both of these relationships. They can affect the relationships by changing the values of the parameters, which suggests the relationships are not stable; or they can change the value of the conditioning variables, which can affect outcomes whether or not the relationships are stable. Our analysis emphasizes the stability of the relationships by identifying those aspects of the relationships for which the parameters don't change. When the parameters change, however, we note important changes in the means of the conditioning variables that can be suggestive of explanations.

If for any subset of conditioning variables the parameters are stable in study $1(\delta=0)$, one would confidently conclude that the passage of the law and associated macroeconomic changes over the nine years had no effect on the inter-temporal stability of this aspect of the behavioral relationship. If for the same subset of conditioning variables, one also finds a stable relationship in study $2(\delta=0)$, one would also confidently conclude that the choice of location of the new gas stations had no impact on the inter-temporal stability of this behavioral relationship.This result would reveal a very stable feature of the relationship with respect to the passage of the law and any other changes occurring during these nine years.

Finally, we note that all of the results presented in the paper are based on robust standard errors that adjust for the clustering of observations by gas stations in both study 1 (14 clusters, 7 in 1998 and 7 in 2007) and study 2 (11 existing stations and 4 new ones). The rationale for the correction is to adjust for the fact that the assumption of identically and independently distributed disturbance terms for observations across clusters is unlikely to hold (e.g., Deaton 1997). Intuitively, common events that affect a particular cluster (gas station in a sample year in our case) can impact all respondents in that cluster in a similar manner affecting either the variance or the correlation of the disturbance terms within the cluster. For instance, the common event may lead to responses that are not independent of each other but exhibit some correlation within the cluster.

\section{Study 1: Inter-Temporal Stability Results}

In this section we present the results of our analysis of the passage of the law and associated macroeconomic changes that affect market environments on customer satisfaction and future patronage intentions for existing 
establishments. We do this by analyzing the constructed data set using the surveys in 1998 and 2007 for the same seven stations. We estimated a variety of specifications of equation 3 for both customer satisfaction and future patronage intentions.

Table 1 contains the results (in abbreviated form) of estimating the most general specification for customer satisfaction. This specification included all five distribution services, all demographic variables and consumer characteristics and two objective variables at the same time.

Table 1. Customer satisfaction: study 1

\begin{tabular}{llll}
\hline Parameters for $\mathbf{1 9 9 8}$ & \multicolumn{3}{l}{ Regression } \\
& Variable & Coefficient & T-Ratio \\
\hline Constant & Constant & 9.498 & 15.170 \\
Assurance & {$\left[10-\mathrm{D}_{4}\right]$} & -.399 & -4.880 \\
Ambience & {$\left[10-\mathrm{D}_{5}\right]$} & -.264 & -4.080 \\
Prices & $\mathrm{X}_{6}$ & -.137 & -2.460 \\
Frequency of purchases at the station & $\mathrm{X}_{13 \mathrm{~b}}$ & .041 & 2.240 \\
\hline Changes between 2007 and $\mathbf{1 9 9 8}$ & & & \\
& & Regression & \\
& Variable & Coefficient & T-Ratio \\
\hline Prices & $\mathrm{DX}_{6}$ & .201 & 2.690 \\
\hline $\mathrm{N}=$ & 516 & $\mathrm{R}^{2}=$ & .4671 \\
\hline
\end{tabular}

The top half of the table presents the parameter estimates (and their t-ratios) for 1998 that were statistically significant at least at the .05 level for each of the three types of variables as well as any that would have a statistically significant change in 2007, regardless of their statistical significance in 1998 . The second half of the table presents the corresponding estimates of changes in these parameters between 2007 and 1998. In order to prevent clutter we do not present the purely demographic variables in Table 1 even if statistically significant. For, they were used as controls and have no particular interpretative value in the present context.

With respect to distribution services the main result emerging from Table 1 is that prior to passage of the law consumer's perceptions of two distribution services, assurance of product delivery at the desired time and ambience, had a substantial positive effect on customer satisfaction in terms of both statistical significance and magnitude of impact and this impact was not affected by the law or by the associated macroeconomic events of the following nine years. The hypothesis of inter-temporal stability in these two parameters can not be rejected at levels of significance considerably higher than .05. Thus the passage of the law is unlikely to have had any effect on the impact of distributions services on customer satisfaction, regardless of whatever else was changing during this nine year period.

These results are not affected by the dropping of other type of variables from the regression at the same time. For instance, if we dropped all other consumer characteristics and their changes from the regression (including the demographic variables), the estimates for these two distribution services would be - .44 and -.27 , respectively, they would both be statistically significant at well beyond the .05 level and their changes would be statistically insignificant with t-ratios well below 1 . Not surprisingly, since the two objective variables included in the general regression (the level of competition and the number of cars that can be handled simultaneously by a station) are statistically insignificant, dropping the objective variables from the regression has no effect on the other results.

With respect to consumer characteristics an interesting result emerging from Table 1 is that a perception of high prices had a negative impact on satisfaction before the passage of the law, but that this impact changed to a positive one afterwards. The most obvious interpretation is that the perception of store price level is not a stable determinant of customer satisfaction. Nevertheless, since the law impacted prices of the main product offered by the establishment directly, we present other more nuanced interpretations below.

For instance, these gas stations sold items other than gas, for example car washes, simple repair services and some convenience store items. The prices of these other products were not fixed by the government in 1998.In this setting a change of impact from negative to positive is consistent with the view that gas prices played no role in perceived store price level before the passage of the law, since they were constant, but did so afterwards. 
Consumers' dissatisfaction with high prices before passage of the law referred to the prices of other products. After the passage of the law consumers may not have liked the higher prices overall, but had a wider choice of stations and chose the one they were sampled at because other dimensions predominated in the station choice. Thus, the positive effect on satisfaction in 2007 reflects the additional choices in terms of stations in 2007 and that the choice could now incorporate all margins, including gas prices. A more narrow interpretation is that the positive impact after the passage of the law simply reflects a reallocation of price sensitive consumers to low priced competitors.

One customer characteristic worth highlighting is frequency of purchases at the gas station. For, it plays the role of a control mechanism for possible selection effects since the consumers were sampled at the station. It has a positive impact on customer satisfaction that does not change after the price liberalization. This result continues to hold if we drop the objective variables from the analysis. It also continues to hold if we drop distribution services from the analysis. Furthermore we note that other results remain the same if we drop this variable from the specification. This indicates that selection is not an issue in our context of customer satisfaction with a transaction.

Putting these results in perspective we note that dropping the objective variables from the regression reported in Table 1 drops the $\mathrm{R}^{2}$ to .46 . Dropping the consumer characteristics, including demographic variables, drops the $\mathrm{R}^{2}$ to .41. But, dropping distribution services reduces the $\mathrm{R}^{2}$ to .18. Table $2 \mathrm{~A}$ in the Statistical Appendix shows that customer satisfaction with the seven gas stations surveyed in both years increased by .61 or $8.64 \%$. This average increase was statistically significant at the $1 \%$ level. The change in the means of the two distribution services that are statistically significant accounts for $41 \%$ of this increase.

A tangential but interesting aspect of our results in study 1 is that they provide empirical evidence for the literature on psychological implications of customer participation in co-production. Our empirical results indicate that pleasure in pumping gas has no effect on customer satisfaction before or after passage of the law. This evidence casts doubts on the suggestion (Van Raaij \& Pruyn, 1998) that the greater the sense of control the greater the satisfaction with the service. This same evidence supports an alternative hypothesis (Bendapudi \& Leone, 2003). Namely, when an outcome is as expected a customer who participates in production will be as satisfied with the firm as will a customer who does not participate in production. Since the activity of pumping gas is likely to result in an outcome as expected, our results support this hypothesis and its underlying explanation of self serving bias in participation and its impact on satisfaction. This is more noticeable because there are no price differences between self service and other stations in 1998 and the possible factor of a lower price for co-production is irrelevant in 1998.

With respect to the relation between future patronage intentions and its determinants, we should first address an econometric issue that arises due to the typical specification in the literature. If customer satisfaction is part of a system with future patronage intentions, which is implied by the literature that postulates links from attributes or services to satisfaction and then from satisfaction to performance as captured in equation (2), the error or disturbance terms in both equations could be correlated. Since many of the same unobservable events between 1998 and 2007 (or affecting existing and new firms) would affect both customer satisfaction and future patronage intentions, this is a likely situation. Ignoring this correlation in the estimation of the relation between satisfaction and performance would in general yield biased estimates due to their being part of a simultaneous system (e.g., Wooldridge, 2003).

A simple solution is to use the estimated values of customer satisfaction in implementing equation (2) rather than the observed ones. This is the procedure followed in estimating equation (3) for future patronage intentions. That is, we used estimated customer satisfaction from the previous section rather than actual customer satisfaction in all the regressions reported in Table 2. This table shows in abbreviated form the results from the most general specification estimated with the data for study 1. Just as in Table 1 the top half represents parameter estimates for 1998 that were statistically significant at least at the .05 level for each of the three types of variables as well as any that would have a statistically significant change in 2007. Similarly, the bottom half presents the corresponding estimates of changes in these parameters between 1998 and 2007 and we do not include the purely demographic variables in the text tables regardless of statistical significance. 
Table 2. Future patronage intentions: study 1

\begin{tabular}{llll}
\hline Parameters for $\mathbf{1 9 9 8}$ & \multicolumn{3}{l}{ Regression } \\
\hline & Variable & Coefficient & T-Ratio \\
\hline Estimated customer satisfaction & $\mathrm{S}^{\wedge}$ & .514 & 4.050 \\
Inter-purchase time of gas & $\mathrm{X}_{13 \mathrm{~A}}$ & -.051 & -3.600 \\
Frequency of purchases at the station & $\mathrm{X}_{13 \mathrm{~B}}$ & .512 & 12.360 \\
$\mathrm{~N}^{\circ}$ competitors 5 kms. & $\mathrm{O}_{6}$ & -.018 & -.570 \\
\hline Changes between 2007 and 1998 & & & \\
& & Regression & \\
& Variable & Coefficient & T-Ratio \\
\hline Inter-purchase time of gas & $\mathrm{DX}_{13 \mathrm{~A}}$ & .068 & 2.190 \\
Frequency of purchases at the station & $\mathrm{DX}_{13 \mathrm{~B}}$ & -.334 & -4.440 \\
$\mathrm{~N}^{\mathrm{o}}$ competitors 5 kms. & $\mathrm{DO}_{6}$ & .090 & 2.480 \\
\hline $\mathrm{N}=$ & 516 & $\mathrm{R}^{2}=$ & .4436 \\
\hline
\end{tabular}

Substantively a very important result to emerge from Table 2 is the inter-temporal stability of customer satisfaction as a determinant of future patronage intentions. Estimated customer satisfaction has a positive and statistically significant impact $(\mathrm{p}=.001)$. It is substantial in magnitude and its effect is the same in 1998 as in 2007. Thus, an important aspect of the relationship between customer satisfaction and future patronage intention stressed in the literature is most unlikely to have been affected by the passage of the law and subsequent macroeconomic events.

With respect to customer characteristics, however, Table 2 reveals a different picture. Prior to passage of the law the inter-purchase time of gas decreases future patronage intentions while, not surprisingly, the frequency of purchases of gas at the station increases future patronage intentions. Both of these effects change in the subsequent nine years. While the impact of inter- purchase time of gas becomes positive, it is quite small in magnitude; in contrast, the impact of frequency of purchases of gas at the station decreases substantially but remains positive and sizable in magnitude.

Finally, the two objective variables included in the most general estimation were the level of competition faced by the station and whether or not self- service was offered by the station. While self-service was not statistically significant when included with the level of competition, it was when included by itself as well as in study 2 and, thus, we chose this one as the most general specification. While the level of competition did not matter before passage of the law, an increase in this level increases future patronage intentions after the liberalization.An intuitive explanation for this seemingly unusual result is that it is a consequence of a new equilibrium in the Pamplona market. Existing establishments have adjusted to the consequences of entry and exit over this nine year period by emphasizing the services that appeal to a subset of their original customers and others with similar preferences. This explanation is consistent with the argument that increased competition leads to more players willing to differentiate themselves (Johnson et al., 2006).

The descriptive statistics presented in Table 2A of the Statistical Appendix support this interpretation. Both customer satisfaction and future patronage intentions increase over the nine year period and the increase is statistically significant. Many distribution services, customer characteristics and objective features of these establishments also exhibit statistically significant changes. For instance, in 2007 the customers that patronize these existing establishments perceive them as more accessible and informative as well as providing more assurance and better ambience than in 1998. The nature of the customers also changed. These establishments are now patronized by more females and more patrons older than 25 as well as by more married ones. In 2007 patrons make larger and more infrequent purchases but visit the station more often while searching for alternative establishments less often than in 1998. In terms of statistically significant differences in objective characteristics, 2007 reveals existing stations that display prices, have more aisles, charge higher prices and face more competitors than in 1998.

While the remaining results are not affected by eliminating estimated customer satisfaction or the objective variables from the regression, they are sensitive to dropping customer characteristics from the regression. More specifically, dropping these characteristics lowers the $\mathrm{R}^{2}$ in Table 2 to $21 \%$ and changes some individual results dramatically. For instance, the magnitudes of coefficients for estimated satisfaction and self-service almost double in size in absolute value. One of the customer characteristics is frequency of purchases at the gas station. 
Since this variable captures factors that may have led to the selection of the gas station by consumers in the past, its elimination can lead to other variables artificially picking up its effect.

To further explore this issue we re-estimated our most general specification dropping frequency of purchases at the gas station from the regression. The results are presented in Table 4A of the Statistical Appendix using the same format as Table 2. We find a similar dramatic doubling of the above two coefficients in terms of magnitudes. On the other hand, a number of other variables become statistically significant (at the $p<.05$ level) and others become statistically insignificant. Thus, including the frequency of purchases at the gas station is useful and necessary as a mechanism to control for sample selection. By contrast, in the case of customer satisfaction this variable had little if any impact on other results. To conclude this section we note that the predictive ability of the three types of variables in explaining customer satisfaction or future patronage intentions for existing stations over this nine year period is very similar: The $\mathrm{R}^{2}$ is .467 for customer satisfaction and .444 for future patronage intentions.

\section{Study 2: Geographical Stability Results}

One can think of the previous results as reflecting the effects of passage of the law and macroeconomic changes over this nine year period given that location is fixed. In the context of retailing this variable has been recognized as one of special importance in determining outcomes (e.g., Jones and Simmons 1993). Nonetheless, keeping the location of existing establishments fixed does not control for the effects of entry and exit in this market. Indeed, the previous results have been shown to incorporate some of those effects.Moreover, in the case of gas stations consumers would be expected to have greater mobility than in other settings. In this section we focus on the possible effects of changes associated with this important characteristic of the market environment.

In study 2 we analyze explicitly the effects of allowing location to vary on the stability of these two marketing relationships. We use the same methodology to compare customer satisfaction with existing stations with customer satisfaction with new stations after the passage of the law and associated macroeconomic changes that impact market environments. Just as in the case of differences over time, the lack of differences between the two types of stations can be viewed as convincing evidence that the marketing relationships are the same, regardless of location and whatever other factors changed for the two types of stations. Changes in the impacts of parameters between existing and new stations, however, need to be viewed more cautiously. They represent possible differences worthy of further scrutiny in search of possible explanations.

This sample consists of 15 stations. Of these, 11 existed in 1998 and 4 were built since that time. The 11 existing since 1998 include the 7 used previously and the results for existing stations in study 2 provide an additional check on the robustness of our earlier results. We estimated the same most general specification as in study 1 for customer satisfaction and we present the results in the same abbreviated form in Table 3.

Just as in study 1, the top half of the table presents the parameter estimates (and their t-ratios) for the existing stations that were statistically significant at least at the .05 level for each of the three types of variables as well as any that would experience a statistically significant change in 2007. Similarly, the bottom half presents the corresponding estimates of changes in these parameters between existing and new stations. Incidentally, no purely demographic variable had a statistically significant effect in 2007 for either the new or the existing stations. This suggests that the few effects of these variables in study 1 were due to sampling variability.

With respect to distribution services Table 3 confirms the main result of study 1. First, the same two distribution services, assurance and ambience, that determined customer satisfaction in 1998 and 2007 for the stations surveyed in both years also determine customer satisfaction for all 11 stations existing in 1998. Second, the impact of these two distribution services on customer satisfaction is the same for both existing and new stations. Thus, the conclusion that passage of the law and associated macroeconomic changes had no effect on the relationship between these two distribution services and customer satisfaction is as convincing as one can get in empirical work. For, it is not sensitive to the choice of location. 
Table 3. Customer satisfaction: study 2

\begin{tabular}{|c|c|c|c|}
\hline \multicolumn{4}{|l|}{ Parameters for 1998} \\
\hline & \multicolumn{3}{|c|}{ Regression } \\
\hline & Variable & Coefficient & T-Ratio \\
\hline Constant & Constant & 7.601 & 14.670 \\
\hline Information & {$\left[10-\mathrm{D}_{2}\right]$} & .005 & .130 \\
\hline Assurance & {$\left[10-\mathrm{D}_{4}\right]$} & -.426 & -7.730 \\
\hline Ambience & {$\left[10-\mathrm{D}_{5}\right]$} & -.242 & -4.130 \\
\hline Prices & $\mathrm{X}_{6}$ & .078 & 2.390 \\
\hline Size of purchases & $\mathrm{X}_{12}$ & .003 & .890 \\
\hline Inter-purchase time of gas & $\mathrm{X}_{13 \mathrm{~A}}$ & -.019 & -2.350 \\
\hline $\mathrm{N}^{\mathrm{o}}$ of cars & $\mathrm{O}_{2}$ & .002 & .140 \\
\hline $\mathrm{N}^{o}$ competitors $5 \mathrm{kms}$. & $\mathrm{O}_{6}$ & .029 & 2.380 \\
\hline \multicolumn{4}{|c|}{ Changes between 2007 and 1998} \\
\hline & \multicolumn{3}{|c|}{ Regression } \\
\hline & Variable & Coefficient & T-Ratio \\
\hline Information & $\mathrm{DD}_{2}$ & -.165 & -2.670 \\
\hline Prices & $\mathrm{DX}_{6}$ & -.180 & -2.890 \\
\hline Size of purchases & $\mathrm{DX}_{12}$ & -.013 & -2.510 \\
\hline $\mathrm{N}^{\mathrm{o}}$ of cars & $\mathrm{DO}_{2}$ & .259 & 2.400 \\
\hline $\mathrm{N}^{o}$ competitors $5 \mathrm{kms}$. & $\mathrm{DO}_{6}$ & -.097 & -4.010 \\
\hline $\mathrm{N}=$ & 570 & $\mathrm{R}^{2}=$ & .4366 \\
\hline
\end{tabular}

A novel and interesting result on distribution services is that for new stations the provision of information about products, services and prices has a positive impact on customer satisfaction even though it has no effect for existing ones. A plausible explanation is that the new stations serve a different clientele base, which is more demanding of this type of service. We will provide evidence on this explanation below.

With respect to customer characteristics the main result in Table 3 is that perception of high prices increases customer satisfaction for existing stations while decreasing it for new stations. Once again the first part of the result confirms what we found in study 1 and it makes the interpretation of a positive perception between the level of prices and customer satisfaction as a result of a new equilibrium in the market for gas stations more convincing. The second part of the result, namely a negative relation between perceptions of high prices and customer satisfaction for new stations, is suggestive of the new stations catering to a different client base than the existing ones.

A similar situation arises with respect to the size of purchases. This variable did not matter in study 1 and it does not matter for existing establishments in study 2 . On the other hand, it does have a statistically significant impact on customer satisfaction for new establishments. Once again this result suggests that the client base of each type of establishments is different. Customers that make large purchases would be less satisfied at new stations.

With respect to other characteristics of consumer buying habits we find that the inter-purchase time has a negative effect on satisfaction which is the same for existing and new stations. While this may seem a contradiction with study 1 , since no effect was found there, the contradiction is the result of sampling variability. The result that this variable mattered for the seven firms in 2007 in study 1 had a p value of .056, and was thus excluded from Table 1, whereas in study 2 it had a p value of .034, and was thus included in Table 3.

Similarly, frequency of purchases at the gas station had a positive impact on customer satisfaction in study 1 and does not appear here for existing or new establishments. Sampling variability is again the culprit. The impact of this variable on customer satisfaction at existing establishments has a p value of .068 in study 2, and was thus excluded from the table. Finally, given this variable's role as a control for selection we dropped it from the analysis to see if it affected the other results. It did not.

Turning to the objective characteristics of gas stations, our main result in Table 3 is that increases in competition increase satisfaction for existing establishments but decrease satisfaction for new establishments. Thus, we have another result that suggests a different client base for existing establishments and for new establishments. It also turns out that the number of cars that can be handled simultaneously has no effect on existing establishments but increases satisfaction for new establishments. Once again this suggests a different client base for the two types of establishments. Both this result and the one on information discussed above are consistent with the finding for 
Korean gas stations that the reaction to price wars after price liberalization is heterogeneous among establishments. Some stations have a differential advantage in facilities or gift coupons; thus, they react differently (with more instruments) to price competition than those without these advantages (Shin, 2004).The provision of additional information services and the facility advantage of handling more cars simultaneously can be viewed as a response to the changed market environment by new establishments. This response diminishes the need to rely solely on the price instrument.

As the reader may recall, in study 1 neither one of these two objective variables have an impact.We suspected that the lack of variability in these variables may have been a reason for this in study 1 . We only had seven different stations whereas here we have fifteen different ones. As a check we re-estimated our most general specification with the seven stations used in study 1 and the four new ones. Our suspicions were confirmed, we find that the t-ratios for these two variables in existing establishments are well above the .05 cut off value.

Just as in the case of study 1 we dropped each of the three types of variables from the analysis to see the impact on the results. Dropping all distribution services reduced the $\mathrm{R}^{2}$ in Table 3 to .24 ; dropping all customer characteristics, including demographic ones, reduced the $\mathrm{R}^{2}$ to .40 ; and dropping the objective variables reduced the $\mathrm{R}^{2}$ to .43 . In each case the main results were not affected. In Table $3 \mathrm{~A}$ of the Statistical Appendix we see that there is a statistically significant drop in customer satisfaction between the existing stations and the new ones of about $5 \%$. The drop in the average perceived levels of a distribution service that is statistically significant and that has a statistically significant impact on satisfaction (assurance of product delivery at the desired time) alone accounts for $60 \%$ of this drop in customer satisfaction with the new stations.

Earlier we highlighted possible differences in the client base for each type of establishment as potential explanations for many of the results in this second study that indicated differences in the relationship between existing and new establishments. By relying on the descriptive statistics in Table 3A of the Statistical Appendix we can identify these differences as well as indicate what the objective differences in the two types of stations may be. The new stations on average have more aisles, provide an opportunity to handle more cars simultaneously, face a higher number of competitors and provide higher levels of self service than existing ones. Moreover, the average level of the price of diesel in the new stations is lower than in existing ones. Not surprisingly the customers of new stations expressed a higher average level of pleasure in pumping gas and a higher average willingness to search for other gas stations. The average level of perceived accessibility of location is also lower for the new stations than for the existing ones as is the average level of assurance of product delivery at the desired time. On the demographic side the new stations are patronized more often by single customers and less so by those aged 25 to 40 years old. All these differences were statistically significant at the $1 \%$ level. At the $5 \%$ level of significance, we can also conclude that customers of new stations on average attach more importance to the amount of time spent at the station and perceive slightly lower levels of prices.

Having a systematic description of the differences between the two types of stations and their client bases allows us to provide a broader interpretation of the role of location on the determinants of customer satisfaction. Since the existing stations had a "first mover advantage" in terms of location, the new stations that come in after the passage of the law compete on price, provision of self-service, and handling of more cars at the same time. The customers that choose to frequent these stations on average are more likely to pump their own gas, search for other stations more often, and face somewhat lower prices. Nonetheless, they are less satisfied with the accessibility of these new stations and with the timeliness of the service they get so that overall they are less satisfied with these stations than the customers of the existing ones even though the latter face less competition from other stations.

Once we allow for the choice of location to vary, the passage of the law and associated macroeconomic changes result on average in increased customer satisfaction for existing stations and decreased customer satisfaction in new ones relative to the levels prevailing for existing ones prior to the passage of the law. This happens despite the existence of lower average prices of diesel for the new stations and the perception that average prices in these new establishments are also lower than in existing ones. Finally, the ability of these three types of variable to predict customer satisfaction in new and existing stations is similar to their ability to predict customer satisfaction in 1998 and 2007: The $\mathrm{R}^{2}$ in the former is .437 while in the latter is .467.

We use the same methodology to compare future patronage intentions for existing stations with future patronage intentions for new stations after passage of the law. We estimated the same most general specification as in study 1 for future patronage intentions and present the results in the same abbreviated form in Table 4. 
Table 4. Future patronage intentions: study 2

\begin{tabular}{llll}
\hline Parameters for 1998 & \multicolumn{3}{l}{ Regression } \\
& Variable & Coefficient & T-Ratio \\
\hline Constant & Constant & 2.85 & 2.62 \\
Estimated customer satisfaction & $\mathrm{S}^{\wedge}$ & .51 & 2.79 \\
Searches for other stores & $\mathrm{X}_{16}$ & -.15 & -2.81 \\
Frequency of purchases at the station & $\mathrm{X}_{13 \mathrm{~B}}$ & .23 & 4.97 \\
Self-service & $\mathrm{O}_{1}$ & -.55 & -2.95 \\
$\mathrm{~N}^{\circ}$ competitors 5 kms. & $\mathrm{O}_{6}$ & .05 & 1.94 \\
\hline Changes between 2007 and $\mathbf{1 9 9 8}$ & & & \\
\hline & & Regression & \\
& Variable $^{\wedge}$ & Coefficient & T-Ratio \\
\hline Estimated customer satisfaction & $\mathrm{DS}^{\wedge}$ & .55 & 2.07 \\
$\mathrm{~N}^{\circ}$ competitors 5 kms. & $\mathrm{DO}_{6}$ & -.32 & -6.05 \\
Self-service & $\mathrm{DO}_{1}$ & 1.08 & 3.00 \\
\hline $\mathrm{N}=$ & 570 & $\mathrm{R}^{2}=$ & .3094 \\
\hline
\end{tabular}

Estimated customer satisfaction has a positive and statistically significant impact on future patronage intentions for these 11 existing stations. Indeed, if we round off to two decimals the estimated parameter value is the same for the 11 existing stations in study 2 as for the 7 in study 1 . The impact for new stations is also positive and statistically significant but far greater in magnitude, which implies that this aspect of the relationship is more important for new stations than it is for existing stations. Thus, once we allow location to vary the future patronage intentions relationship is not robust or stable with respect to new establishments. The latter are far more sensitive to customer satisfaction than existing establishments.

With respect to customer characteristics, Table 4 shows two stable characteristics: those more inclined to search had lower patronage intentions and those purchasing gas more frequently at the station had higher levels of future patronage intentions for both new and existing stations. With respect to the objective variables there are two unstable characteristics. Whether or not the station offered self-service decreases future patronage intentions for existing stations and increases these intentions for new ones. This suggests a different client base for each type of station. An increase in competition lowers future patronage intentions for new stations but not for existing ones, which again suggests different client bases.

Evaluating the robustness of these results we find that the $\mathrm{R}^{2}$ decreases from .31 in Table 4 to .26 if estimated customer satisfaction is eliminated; it decreases to .20 if consumer characteristics, including demographic ones, are eliminated; and, finally, it decreases to .28 if the objective ones are eliminated. A standard F-test rejects the null hypothesis that the eliminated variables do not contribute to the explanation of future patronage intentions at the $1 \%$ level in all three cases. Notice that predictive ability in explaining future patronage intentions for new and existing stations is much lower than for any of the other estimated relationships. For completeness, we dropped the frequency of purchases of gas at the station from the most general specification. The results comparable to Table 4 are presented in Table 5A of the Statistical Appendix. Once again there are noticeable changes in the results, just as in study 1.

To conclude, the more salient result of the analysis of future patronage intentions is that the passage of the law and associated macroeconomic changes, including the full process of entry and exit, seem to have led to a very different relationship for existing establishments than for new establishments. The impact of customer satisfaction on future patronage intentions is twice as large for new establishments. Moreover, the impact of the objective variables (intensity of competition and self-service) differs between new establishments and existing ones. These results also confirm the ones for customer satisfaction by providing further evidence that each type of establishment faces a different client base.

\section{Concluding Remarks}

We have established rather convincingly that the macroeconomic events affecting the market environment for gas stations in Pamplona, including passage of a law that affects the price of the main product sold by these retail establishments, had no effect on two of the distribution services or attributes that determine customer satisfaction for existing and new establishments: Namely on assurance and ambience. On the other hand, these events affected one aspect of this marketing relationship for new establishments. For patrons of these establishments 
one distribution service, namely perception of the display of information on prices, products and services, became an additional determinant of customer satisfaction. Thus, two of the main managerially relevant aspects of this marketing relationship are inter-temporally and geographically stable for existing and new establishments but a third one is sensitive to an important aspect of the market environment, location, and relevant only for new establishments.

With respect to customer characteristics we found two inter-temporal and geographically stable results for customer satisfaction. The macroeconomic events of these nine years had no effect on the impact of inter-purchase time of gas (decreasing) and frequency of purchases at the station (increasing) on customer satisfaction for existing or new establishments, once sampling variability is accounted for. On the other hand, these events changed the direction of the impact of perceptions of prices relative to other establishments on customer satisfaction from positive for existing establishments to negative for new establishments. This change suggested the existence of a different client base for existing and new establishments. The descriptive data confirmed that new establishments cater to a more price sensitive clientele which is offered lower prices by the new stations as well as lower levels of accessibility of location and assurance of product delivery at the desired time. Not surprisingly, patrons of new stations experience lower levels of customer satisfaction.

Incidentally these results have implications for the literature on pricing strategies. A recent survey (Kopalle et al., 2009) identifies store/positioning format as one of seven factors impacting retailer pricing strategies in cross-channel competition. The results just discussed imply an equally important role in impacting retailers pricing strategies through in-channel competition. The main factors viewed as impacting strategy in terms of in-channel competition in the literature are pricing mechanisms such as loss leader strategy. Yet the same interaction between prices and distribution services observed for cross-channel competition and suggested and tested for supermarkets (Lal \& Rao, 1997; Richards \& Hamilton, 2006) arises for in-channel competition for gas stations between incumbents and new entrants.

In general we find that the marketing relationship between future patronage intentions and its three main types of determinants tends to exhibit less inter-temporal stability and less geographical stability than the marketing relationship between customer satisfaction and its three main types of determinants. For instance, the impact of the most important variable from a managerial point of view, customer satisfaction, on future patronage intentions is inter-temporally stable but very unstable geographically to the passage of the law freeing gas retail prices and to the associated macroeconomic events of the subsequent nine years. Managers of new stations face a situation where customer satisfaction has twice the impact in magnitude on future patronage intentions than managers of existing stations!

With respect to customer characteristics, both the inter-purchase time of gas and the frequency of purchases of gas at the station are inter-temporally unstable while the frequency of purchases at the station is geographically stable. The impact of the number of competitors on future patronage intentions is geographically unstable, non-positive for existing stations and negative for new ones. Just as in the case of customer satisfaction, this result seems to be a consequence of a new equilibrium in the market for gas stations in Pamplona after the passage of the law, associated macroeconomic events and the working out of the entry and exit process. Similarly, the existence of self-service lowers future patronage intentions for customers of existing stations while raising them for customers of new stations.

Incidentally, the greater instability of results for future patronage intentions has implications for the retailing literature. Some authors have argued that there is a difference between behavior and intentions and that what matters in the context of retailing is behavior not intentions. While this argument has been made more forcefully in the context of moderating effects rather than direct effects (Seiders et al., 2005), our results suggest that it may also apply to direct effects.

Our research also has limitations that suggest potentially fruitful areas for further research. We have emphasized results that are stable with respect to macroeconomic events because they are the more convincing or reliable ones. But some of the ones that are unstable or change due to these events are quite interesting and worthy of exploration. What we have to say about them is more of a suggestive nature precisely because of the many things that are changing. In our setting this limitation is diminished in three ways: by having a physical product that is the same before and after the passage of the law that freed its price; by keeping location fixed in the first study; and, finally, by observing the changes in the descriptive variables that affect the marketing relationships of interest both before and after the passage of the law as well as between existing and new establishments. Nonetheless, a more direct approach to the changes identified here, especially those characterizing the differences between existing establishments and new, would be a worthwhile undertaking for future research. 
Another limitation of the research is that it may be subject to what has been referred to in the psychological literature as common method bias (Podsakoff et al., 2003). A potentially important situation for this bias to arise is survey research where the respondent answers questions about both the dependent variables and the ones used to explain them, which is the case here. The fact that some distribution services, measured on the same basis as customer satisfaction, matter statistically and others have no effect suggests that this problem is not a serious one in our data. Similarly the fact that what matters for our two dependent variables, which are measured in the same manner, differs also suggests that this problem is not relevant in our context. The possibility of this source of bias in our context is also substantially diminished by the use of different survey sites, interviewers per site and years as well as by our use of clustering by survey site and year in all of our statistical analyses. Finally, there is also recent research in the psychological literature showing that common method bias as a mechanism for inflating correlations has been substantially overstated (Spector, 2006).

To conclude we note that the understanding of the marketing relationship between future patronage intentions and its determinants seems less solid than between customer satisfaction and other performance variables, for example profits. Hence, a similar analysis of the effects of macroeconomic events that affect market environments on customer satisfaction and other performance variables would be a productive area for future research.

\section{Acknowledgements}

Earlier versions of this paper were presented at Rensselaer Polytechnic Institute, University of Maryland, Universidad Pública de Navarra, Universidad Autónoma de Madrid and Universidad Autónoma de Barcelona as well as at the 2010 conferences of IIOC in Vancouver and of INFORMS in Cologne. We are very grateful to the participants for their comments, especially Praveen Kopalle, Gina O'Connor and Marc Remer, as well as to Brian Ratchford for his written comments. Any remaining errors are our responsibility. The authors acknowledge financial support for this research from the Spanish Ministry of Education and Science: Project SEJ2005-0663/ECON.

\section{References}

Anderson, E., \& Mittal, V. (2000). Strengthening the Satisfaction Profit Chain. Journal of Service Research, 3(2), 107-120. http://dx.doi.org/10.1177/109467050032001

Anderson, E., \& Sullivan, M. (1993). The Antecedents and Consequences of Customer Satisfaction for Firms. Marketing Science, 12(Spring), 125-143. http://dx.doi.org/10.1287/mksc.12.2.125

Anderson, E., Fornell, C., \& Lehman, D. (1994). Customer Satisfaction, Market Share and Profitability. Journal of Marketing, 58(3), 53-66. http://dx.doi.org/10.2307/1252310

Anderson, E., Fornell, C., \& Mazvancheryl, S. (2004). Customer Satisfaction and Shareholder Value. Journal of Marketing, 68(October), 172-185. http://dx.doi.org/10.1509/jmkg.68.4.172.42723

Banco de España. (2008). InformeAnual. Retrieved from http://www.bde.es/webbed/es/secciones/informes/publicaciones_an/Informe_anual/anoactual/

Barber, C. L., \& Tietje, B. (2004). A Distribution Services Approach for Developing Effective Competitive Strategies Against 'Big Box' Retailers. Journal of Retailing and Consumer Services, 11(2), 95-107. http://dx.doi.org/10.1016/S0969-6989(03)00009-2

Baruch, Y. (1999). Response Rate in Academic Studies- A Comparative Analysis. Human Relations, 52(4), 421-438. http://dx.doi.org/10.1177/001872679905200401

Bello, A., \& Cavero, S. (2008). The Spanish Retail Gasoline Market: New Patterns of Competition since the Liberalization of the Industry. Energy Policy, 36(2), 612-626. http://dx.doi.org/10.1016/j.enpol.2007.10.014

Bendapudi, N., \& Leone, R. (2003). Psychological Implications of Customer Participation in Co-Production. Journal of Marketing, 67(January), 14-28. http://dx.doi.org/10.1509/jmkg.67.1.14.18592

Bentolila, S., Dolabo, J., \& Jimeno, J. (2008). Does Immigration Affect the Phillips Curve? Some Evidence for Spain. European Economic Review, 52(8), 1398-1423. http://dx.doi.org/10.1016/j.euroecorev.2008.07.001

Berry, L., Seiders, K., \& Grewal, D. (2002). Understanding Service Convenience. Journal of Marketing, 66(July), 1-17. http://dx.doi.org/10.1509/jmkg.66.3.1.18505

Betancourt, R. R. (2004). The Economics of Retailing and Distribution. London: Edward Elgar Publishing, Ltd.

Betancourt, R. R., \& Gautschi, D. A. (1988). The Economics of Retail Firms. Managerial and Decision Economics, 9(2), 133-144. http://dx.doi.org/10.1002/mde.4090090208 
Betancourt, R. R., Cortiñas, M., Elorz, M., \&Mugica, J. M. (2007). The Demand for and the Supply of Distribution Services: A Basis for the Analysis of Customer Satisfaction in Retailing. Quantitative Marketing and Economics, 5(3), 293-312. http://dx.doi.org/10.1007/s11129-007-9027-3

Briesch, R. A., Krishnamurthi, L., Mazumdar, T., \& Raj, S. P. (1997). A Comparative Analysis of Reference Price Models. Journal of Consumer Research, 24, 202-214. http://dx.doi.org/10.1086/209505

Bucklin, L. (1978). Productivity in Marketing. Chicago, IL: American Marketing Association.

Clements, B., Jung, H-S., \& Gupta, S. (2007). Real and Distributive Effects of Petroleum Price Liberalization: The Case of Indonesia. The Developing Economies, 45(2), 220-237. http://dx.doi.org/10.1111/j.1746-1049.2007.00040.x

Contín, I., Correljé, A., \& Huerta, E. (1999). The Spanish Gasoline Market: From Ceiling Regulation to Open Market Pricing. The Energy Journal, 20(4), 1-14. http://dx.doi.org/10.5547/ISSN0195-6574-EJ-Vol20-No4-1

Correljé, A. (1990). The Spanish Oil Sector: From State Intervention to Free Trade. Energy Policy, 18(8), 747-755. http://dx.doi.org/10.1016/0301-4215(90)90027-2

Deaton, A. (1997). The Analysis of Household Surveys: A Microeconometric Approach to Development Policy. Baltimore. MD: The Johns Hopkins University Press (for the World Bank). http://dx.doi.org/10.1596/0-8018-5254-4

Gomez, M., McLaughlin, E., \&Wittink, D. (2004). Customer Satisfaction and Retail Sales Performance: An Empirical Investigation. Journal of Retailing, 80(4), 265-278. http://dx.doi.org/10.1016/j.jretai.2004.10.003

Grace, D., \& O'Cass, A. (2005). An Examination of the Antecedents of Repatronage Intentions across Different Retail Formats. Journal of Retailing and Consumer Services, 12(4), 227-243. http://dx.doi.org/10.1016/j.jretconser.2004.08.001

Greene, W. (2007). Econometric Analysis (6th ed.). New York: Prentice Hall.

Gujarati, D. (1970). Use of Dummy Variables in Testing for Equality between Coefficients in Linear Regressions: A Generalization. The American Statistician, 24(5), 18-22.

Imbens, G., \& Wooldrige, J. (2009). Recent Developments in the Econometrics of Program Evaluation. Journal of Economic Literature, 47(1), 5-86. http://dx.doi.org/10.1257/jel.47.1.5

Johnson, M., Herrmann, A., \& Huber, F. (2006). The Evolution of Loyalty Intentions. Journal of Marketing, 70(April), 122-132. http://dx.doi.org/10.1509/jmkg.70.2.122

Jones, K., \& Simmons, J. (1993). Location, Location, Location: Analyzing the Retail Environment (2nd ed.). Toronto: Nelson Thomson Learning.

Kamakura, W., Mittal, V., De Rosa, F., \& Mazzon, J. (2002). Assessing the Service-Profit Chain. Marketing Science, 21(Summer), 294-317. http://dx.doi.org/10.1287/mksc.21.3.294.140

Kopalle, P., \& Lehmann, D. (2006). Setting Quality Expectations When Entering a Market: What Should the Promise Be? Marketing Science, 25(Winter), 8-24. http://dx.doi.org/10.1287/mksc.1050.0122

Kopalle, P., Biswas, D., Chintagunta, P. K., Fan, J., Pauwels, K., Ratchford, B. T., \&. Sills, J. A. (2009). Retailer Pricing and Competitive Effects. Journal of Retailing, 85(March), 56-70. http://dx.doi.org/10.1016/j.jretai.2008.11.005

Lal, R., \& Rao, R. (1997). Supermarket Competition: The Case of Every Day Low Pricing. Marketing Science, 16(1), 60-80. http://dx.doi.org/10.1287/mksc.16.1.60

Luo, X., \& Homburg, C. (2007). Neglected Outcomes of Customer Satisfaction. Journal of Marketing, 71(April), 133-149. http://dx.doi.org/10.1509/jmkg.71.2.133

Malthouse, E., Oakley, J., Calder, B., \& Iacobucci, D. (2004). Customer Satisfaction across Organizational Units. Journal of Services Research, 6(3), 231-242. http://dx.doi.org/10.1177/1094670503259386

Oi, W. (1992). Productivity in the Distributive Trades: The Shopper and the Economics of Massed Reserves. in Z. Griliches, ed. Output Measurement in the Service Sector. Chicago: University of Chicago Press.

Oliver, R. (1999). Whence Customer Loyalty? Journal of Marketing, 63(Special Issue), 33-44. http://dx.doi.org/10.2307/1252099

Podsakoff, P., Mckenzie, S., Lee, J., \& Podsakoff, N. (2003). Common Method Biases in Behavioral Research: A 
Critical Review of the Literature and Recommended Readings. Journal of Applied Psychology, 88(5), 879-903.http://dx.doi.org/10.1037/0021-9010.88.5.879

Richards, T. J., \& Hamilton, S. F. (2006). Rivalry in Price and Variety among Supermarket Retailers. American Journal of Agricultural Economics, 88(3), 710-726. http://dx.doi.org/10.1111/j.1467-8276.2006.00890.x

Rust, R., \& Zahoric, A. (1993). Customer Satisfaction, Customer Retention and Market Share. Journal of Retailing, 69(Summer), 193-215. http://dx.doi.org/10.1016/0022-4359(93)90003-2

Seiders, K., Voss, G. B., Grewal, D., \& Godfrey, A. L. (2005). Do Satisfied Customers Buy More? Examining Moderating Influences in a Retailing Context. Journal of Marketing, 65(October), 26-43. http://dx.doi.org/10.1509/jmkg.2005.69.4.26

Shin, C. (2004). Asymmetric Competitive Reactions: Likelihood and their Determinants in Retail Gasoline Markets. Journal of Business Research, 57(August), 821-828. http://dx.doi.org/10.1016/S0148-2963(02)00462-9

Sirohi, N., McLaughlin, E. W., \& Wittink, D. R. (1998). A Model of Consumer Perceptions and Store Loyalty Intentions for a Supermarket Retailer. Journal of Retailing, 74(2), 223-245. http://dx.doi.org/10.1016/S0022-4359(99)80094-3

Spector, P. (2006). Method Variance in Organizational Research: Truth or Urban Legend. Organizational Research Methods, 9(2), 221-232. http://dx.doi.org/10.1177/1094428105284955

Van Raaij, W. F., \& Pruyn, A. T. H. (1998). Customer Control and Evaluation of Service Validity and Reliability. Psychology and Marketing, 811-832. http://dx.doi.org/10.1002/(SICI)1520-6793(199812)15:8<811::AID-MAR6>3.0.CO;2-8

Wooldridge, J. (2003). Introductory Econometrics: A Modern Approach (2nd ed.). Cincinnati, OH: South-Western College Publishing.

Yu, J., \& Cooper, H. (1983). A Quantitative Review of Research Design Effects on Response Rates to Questionnaires. Journal of Marketing Research, 20(1), 36-44. http://dx.doi.org/10.2307/3151410

\section{Stadistical Appendix}

Table 1A. Variable names

\begin{tabular}{|c|c|c|c|}
\hline Variable name & Symbol & Variable name & Symbol \\
\hline Customer Satisfaction & $\mathrm{S}$ & Life cycle 2 (child $<6$ yrs.) & $\mathrm{X} 92$ \\
\hline Future Patronage Intentions & $\mathrm{P}$ & Life cycle $3(6<$ childage $<14)$ & $\mathrm{X} 93$ \\
\hline Accessibility of Location & D1 & Life cycle 4 (child $>14$ yrs.) & X94 \\
\hline Information & $\mathrm{D} 2$ & Mean length of stay (mins.) & $\mathrm{X} 11$ \\
\hline Assortment & D3 & Size of purchase (2007 euros) & $\mathrm{X} 12$ \\
\hline Assurance & D4 & Infrequency of purchases of gas (inter-purchase time) & $\mathrm{X} 13 \mathrm{a}$ \\
\hline Ambience & D5 & $\begin{array}{l}\text { Frequency of purchases at the station (out of every ten } \\
\text { times) }\end{array}$ & $\mathrm{X} 13 \mathrm{~b}$ \\
\hline Perceived Price & $\mathrm{X} 6$ & Pleasure in pumping own gas & $\mathrm{X} 14$ \\
\hline Gender 0 (male) & $\mathrm{X} 70$ & Importance of time & $\mathrm{X} 15$ \\
\hline Gender (female) & $\mathrm{X} 71$ & Searches for other stores & $\mathrm{X} 16$ \\
\hline Age 0 (less than 25 years) & $\mathrm{X} 80$ & $\begin{array}{l}\text { Self Service } \\
(\text { Self service }=1 \text {, Full service }=0 \text { ) }\end{array}$ & O1 \\
\hline Age $1(25-40$ years $)$ & $\mathrm{X} 81$ & Number of cars & $\mathrm{O} 2$ \\
\hline Age $2(41-60$ years) & $\mathrm{X} 82$ & Display of prices & $\mathrm{O} 3$ \\
\hline Age 3 ( $>$ than 60 years) & $\mathrm{X} 83$ & Number of aisles & $\mathrm{O} 4$ \\
\hline Life cycle 0 (single) & $\mathrm{X} 90$ & Price (2007 euros) & O5 \\
\hline Life cycle 1 (no child) & $\mathrm{X} 91$ & $\mathrm{~N}^{\mathrm{o}}$ competitors $5 \mathrm{kms}$. & O6 \\
\hline
\end{tabular}


Table 2A. Descriptive statistics: study 1

\begin{tabular}{|c|c|c|c|c|c|c|c|c|c|c|}
\hline \multirow{2}{*}{ Symbol } & \multicolumn{2}{|l|}{ Min } & \multicolumn{2}{|l|}{$\operatorname{Max}$} & \multicolumn{2}{|l|}{ Mean } & \multicolumn{2}{|l|}{ S.D. } & \multirow{2}{*}{$\begin{array}{l}\text { Diff } M . \\
(07-98)\end{array}$} & \multirow{2}{*}{$\begin{array}{l}\text { Diff } M \text {. } \\
(t)^{*}\end{array}$} \\
\hline & 98 & 07 & 98 & 07 & 98 & 07 & 98 & 07 & & \\
\hline $\mathrm{S}$ & 1.00 & .00 & 10.00 & 10.00 & 7.06 & 7.67 & 1.80 & 1.71 & .61 & 3.94 \\
\hline $\mathrm{P}$ & .00 & .00 & 10.00 & 10.00 & 6.54 & 7.36 & 2.57 & 2.71 & .82 & 3.51 \\
\hline D1 & .00 & 1.00 & 10.00 & 10.00 & 6.66 & 7.82 & 2.30 & 1.96 & 1.16 & 6.13 \\
\hline D2 & .00 & .00 & 10.00 & 10.00 & 5.69 & 6.33 & 2.63 & 2.62 & .64 & 2.79 \\
\hline D3 & .00 & .00 & 10.00 & 10.00 & 3.88 & 4.31 & 2.93 & 3.22 & .43 & 1.58 \\
\hline D4 & 1.33 & 3.67 & 10.00 & 10.00 & 7.43 & 7.70 & 1.51 & 1.43 & .27 & 2.10 \\
\hline D5 & .00 & .00 & 10.00 & 10.00 & 7.23 & 7.73 & 1.92 & 1.68 & .50 & 3.14 \\
\hline X6 & .00 & 1.00 & 10.00 & 10.00 & 5.66 & 6.28 & 1.73 & 1.56 & .63 & 4.32 \\
\hline X70 & .00 & .00 & 1.00 & 1.00 & .73 & .58 & .45 & .49 & -.14 & -3.49 \\
\hline X71 & .00 & .00 & 1.00 & 1.00 & .27 & .42 & .45 & .49 & .14 & 3.49 \\
\hline X80 & .00 & .00 & 1.00 & 1.00 & .33 & .20 & .47 & .40 & -.13 & -3.29 \\
\hline X81 & .00 & .00 & 1.00 & 1.00 & .41 & .46 & .49 & .50 & .05 & 1.06 \\
\hline X82 & .00 & .00 & 1.00 & 1.00 & .23 & .28 & .42 & .45 & .05 & 1.26 \\
\hline X83 & .00 & .00 & 1.00 & 1.00 & .03 & .06 & .18 & .25 & .03 & 1.72 \\
\hline X90 & .00 & .00 & 1.00 & 1.00 & .40 & .24 & .49 & .43 & -.16 & -4.06 \\
\hline X91 & .00 & .00 & 1.00 & 1.00 & .20 & .34 & .40 & .47 & .14 & 3.64 \\
\hline X92 & .00 & .00 & 1.00 & 1.00 & .13 & .13 & .34 & .34 & .00 & .02 \\
\hline X93 & .00 & .00 & 1.00 & 1.00 & .08 & .14 & .27 & .34 & .06 & 2.23 \\
\hline X94 & .00 & .00 & 1.00 & 1.00 & .19 & .15 & .39 & .36 & -.04 & -1.09 \\
\hline $\mathrm{X}_{10}$ & .00 & .00 & 15.00 & 24.00 & 7.18 & 7.10 & 3.39 & 3.31 & -.08 & -.27 \\
\hline $\mathrm{X}_{11}$ & 1.00 & 1.50 & 30.00 & 15.00 & 5.48 & 5.44 & 3.01 & 2.65 & -.04 & -.15 \\
\hline $\mathrm{X}_{12}$ & 2.79 & 4.00 & 63.66 & 72.00 & 24.87 & 33.85 & 10.19 & 13.36 & 8.99 & 8.62 \\
\hline$X_{13 a}$ & 1.00 & 1.00 & 30.00 & 30.00 & 7.45 & 11.21 & 5.01 & 6.67 & 3.75 & 7.25 \\
\hline $\mathrm{X}_{13 \mathrm{~b}}$ & .00 & .00 & 10.00 & 10.00 & 5.47 & 6.67 & 2.99 & 2.77 & 1.20 & 4.73 \\
\hline $\mathrm{X}_{14}$ & .00 & .00 & 10.00 & 10.00 & 2.80 & 2.62 & 3.35 & 3.35 & -.18 & -.59 \\
\hline $\mathrm{X}_{15}$ & .00 & .00 & 10.00 & 10.00 & 4.07 & 3.80 & 3.02 & 3.39 & -.27 & -.96 \\
\hline $\mathrm{X}_{16}$ & .00 & .00 & 10.00 & 10.00 & 6.51 & 3.51 & 2.84 & 3.16 & -3.00 & -11.33 \\
\hline $\mathrm{O}_{1}$ & .00 & .00 & 1.00 & 1.00 & .31 & .27 & .46 & .44 & -.04 & -.97 \\
\hline $\mathrm{O}_{2}$ & 6.00 & 6.00 & 22.00 & 22.00 & 9.74 & 9.29 & 5.39 & 4.91 & -.44 & -.97 \\
\hline $\mathrm{O}_{3}$ & .00 & .00 & .00 & 1.00 & .00 & .56 & .00 & .50 & .56 & 18.41 \\
\hline $\mathrm{O}_{4}$ & 2.00 & 2.00 & 10.00 & 10.00 & 3.71 & 4.49 & 2.82 & 2.85 & .77 & 3.09 \\
\hline $\mathrm{O}_{5}$ & .927 & .920 & .927 & .972 & .927 & .939 & .000 & .016 & .012 & 12.62 \\
\hline $\mathrm{O}_{6}$ & 3.00 & 3.00 & 12.00 & 18.00 & 9.09 & 13.47 & 2.97 & 4.88 & 4.38 & 12.40 \\
\hline
\end{tabular}

* RobustStudent's T-test withunequal variances 
Table 3A. Descriptive statistics: study 2

\begin{tabular}{|c|c|c|c|c|c|c|c|c|c|c|}
\hline \multirow{2}{*}{ Symbol } & \multicolumn{2}{|l|}{ Min } & \multicolumn{2}{|l|}{ Max } & \multicolumn{2}{|l|}{ Mean } & \multicolumn{2}{|l|}{ S.D. } & \multirow{2}{*}{$\begin{array}{l}\text { Diff } M . \\
(N-O)\end{array}$} & \multirow{2}{*}{$\begin{array}{l}\text { Diff } M \\
(t)^{*}\end{array}$} \\
\hline & Old & New & Old & New & Old & New & Old & New & & \\
\hline $\mathrm{S}$ & .00 & .00 & 10.00 & 10.00 & 7.42 & 7.05 & 1.77 & 1.72 & -.37 & -2.28 \\
\hline $\mathrm{P}$ & .00 & .00 & 10.00 & 10.00 & 7.22 & 6.80 & 2.60 & 2.41 & -.42 & -1.80 \\
\hline $\mathrm{D}_{1}$ & .00 & .00 & 10.00 & 10.00 & 7.38 & 6.73 & 2.35 & 2.53 & -.65 & -2.74 \\
\hline $\mathrm{D}_{2}$ & .00 & .00 & 10.00 & 10.00 & 6.40 & 6.10 & 2.48 & 2.29 & -.30 & -1.34 \\
\hline $\mathrm{D}_{3}$ & .00 & .00 & 10.00 & 10.00 & 4.54 & 4.74 & 3.29 & 2.93 & .20 & .70 \\
\hline $\mathrm{D}_{4}$ & 3.00 & 3.00 & 10.00 & 10.00 & 7.57 & 7.05 & 1.43 & 1.53 & -.52 & -3.66 \\
\hline $\mathrm{D}_{5}$ & .00 & 3.50 & 10.00 & 10.00 & 7.44 & 7.18 & 1.84 & 1.52 & -.25 & -1.67 \\
\hline $\mathrm{X}_{6}$ & .00 & .00 & 10.00 & 10.00 & 5.90 & 5.46 & 2.02 & 2.29 & -.44 & -2.11 \\
\hline $\mathrm{X}_{70}$ & .00 & .00 & 1.00 & 1.00 & .62 & .61 & .49 & .49 & -.01 & -.18 \\
\hline$X_{71}$ & .00 & .00 & 1.00 & 1.00 & .38 & .39 & .49 & .49 & .01 & .18 \\
\hline $\mathrm{X}_{80}$ & .00 & .00 & 1.00 & 1.00 & .21 & .27 & .41 & .45 & .07 & 1.59 \\
\hline $\mathrm{X}_{81}$ & .00 & .00 & 1.00 & 1.00 & .47 & .36 & .50 & .48 & -.11 & -2.30 \\
\hline $\mathrm{X}_{82}$ & .00 & .00 & 1.00 & 1.00 & .26 & .31 & .44 & .46 & .05 & 1.12 \\
\hline $\mathrm{X}_{83}$ & .00 & .00 & 1.00 & 1.00 & .07 & .06 & .25 & .24 & -.01 & -.37 \\
\hline $\mathrm{X}_{90}$ & .00 & .00 & 1.00 & 1.00 & .25 & .38 & .43 & .49 & .13 & 2.96 \\
\hline $\mathrm{X}_{91}$ & .00 & .00 & 1.00 & 1.00 & .34 & .24 & .47 & .43 & -.09 & -2.25 \\
\hline $\mathrm{X}_{92}$ & .00 & .00 & 1.00 & 1.00 & .13 & .07 & .33 & .25 & -.06 & -2.39 \\
\hline $\mathrm{X}_{93}$ & .00 & .00 & 1.00 & 1.00 & .12 & .15 & .32 & .36 & .03 & .99 \\
\hline $\mathrm{X}_{94}$ & .00 & .00 & 1.00 & 1.00 & .17 & .16 & .38 & .37 & -.01 & -.26 \\
\hline $\mathrm{X}_{10}$ & .00 & .00 & 24.00 & 16.00 & 7.16 & 6.98 & 3.29 & 3.22 & -.18 & -.59 \\
\hline $\mathrm{X}_{11}$ & 1.50 & 2.00 & 20.00 & 30.00 & 5.76 & 6.04 & 2.93 & 3.22 & .28 & .95 \\
\hline $\mathrm{X}_{12}$ & 4.00 & 2.00 & 100.00 & 100.00 & 34.23 & 32.81 & 14.61 & 13.34 & -1.42 & -1.10 \\
\hline $\mathrm{X}_{13 \mathrm{a}}$ & .50 & 1.00 & 35.00 & 50.00 & 10.95 & 11.27 & 7.08 & 7.12 & .32 & .48 \\
\hline $\mathrm{X}_{13 \mathrm{~b}}$ & .00 & .00 & 10.00 & 10.00 & 6.52 & 6.05 & 2.82 & 2.66 & -.47 & -1.84 \\
\hline $\mathrm{X}_{14}$ & .00 & .00 & 10.00 & 10.00 & 2.67 & 3.74 & 3.31 & 3.52 & 1.07 & 3.27 \\
\hline $\mathrm{X}_{15}$ & .00 & .00 & 10.00 & 10.00 & 3.94 & 4.54 & 3.26 & 2.93 & .60 & 2.09 \\
\hline $\mathrm{X}_{16}$ & .00 & .00 & 10.00 & 10.00 & 3.33 & 4.29 & 3.16 & 3.01 & .96 & 3.32 \\
\hline $\mathrm{O}_{1}$ & .00 & .00 & 1.00 & 1.00 & .27 & .49 & .44 & .50 & .22 & 4.87 \\
\hline $\mathrm{O}_{2}$ & 4.00 & 8.00 & 22.00 & 12.00 & 8.57 & 9.49 & .85 & 1.83 & .92 & 3.75 \\
\hline $\mathrm{O}_{3}$ & .00 & .00 & 1.00 & 1.00 & .45 & .49 & .50 & .50 & .04 & .83 \\
\hline $\mathrm{O}_{4}$ & 2.00 & 6.00 & 10.00 & 10.00 & 4.62 & 8.00 & 2.63 & 1.41 & 3.38 & 19.64 \\
\hline $\mathrm{O}_{5}$ & .919 & .909 & .972 & .939 & .937 & .924 & .014 & .011 & -.013 & -10.28 \\
\hline $\mathrm{O}_{6}$ & 3.00 & 9.00 & 18.00 & 15.00 & 10.99 & 12.44 & 5.27 & 2.32 & 1.45 & 4.55 \\
\hline
\end{tabular}

* Robust Student's T-test with unequal variances 
Table 4A. Without X13B

\begin{tabular}{llll}
\hline Parameters for $\mathbf{1 9 9 8}$ & \multicolumn{3}{c}{ Regression } \\
& Variable & Coefficient & T-Ratio \\
\hline Constant & Constant & -2.272 & -1.920 \\
Estimated customer satisfaction & $\mathrm{S}^{\wedge}$ & .938 & 6.530 \\
Prices & $\mathrm{X}_{6}$ & .215 & 3.440 \\
Pleasure in pumping gas & $\mathrm{X}_{14}$ & .094 & 2.730 \\
Searches for other stores & $\mathrm{X}_{16}$ & .158 & 1.700 \\
Inter-purchase time of gas & $\mathrm{X}_{13 \mathrm{~A}}$ & -.070 & -2.940 \\
Self-service & $\mathrm{O}_{1}$ & -1.599 & -3.060 \\
\hline Changes between 2007 and $\mathbf{1 9 9 8}$ & & & \\
\hline & & Regression & \\
& Variable & Coefficient & T-Ratio \\
\hline 07Dummy & 07 Dummy & 5.038 & 2.440 \\
Searches for other stores & $\mathrm{DX}_{16}$ & -.405 & -3.520 \\
Inter-purchase time of gas & $\mathrm{DX}_{13 \mathrm{~A}}$ & .090 & 2.610 \\
\hline $\mathrm{N}=$ & 516 & $\mathrm{R}^{2}=$ & .3161 \\
\hline
\end{tabular}

Table 5A. Without X13B

\begin{tabular}{llll}
\hline Parameters for 1998 & & & \\
& & Regression & \\
& Variable & Coefficient & T-Ratio \\
\hline Constant & Constant & 3.44 & 2.97 \\
Estimated customer satisfaction & $\mathrm{S}^{\wedge}$ & .68 & 3.88 \\
Searches for other stores & $\mathrm{X}_{16}$ & -.21 & -4.89 \\
Self-service & $\mathrm{O}_{1}$ & -.63 & -2.97 \\
$\mathrm{~N}^{\mathbf{0}}$ competitors 5 kms. & $\mathrm{O}_{6}$ & .05 & 2.14 \\
\hline Changes between 2007 and 1998 & & & \\
& & Regression & \\
& Variable $^{\wedge}$ & Coefficient & T-Ratio \\
\hline Estimated customer satisfaction & $\mathrm{DS}^{\wedge}$ & .59 & 2.69 \\
Searches for other stores & $\mathrm{DX}_{16}$ & .13 & 2.72 \\
Self-service & $\mathrm{DO}_{1}$ & 1.11 & 3.23 \\
$\mathrm{~N}^{\mathbf{0}}$ competitors $5 \mathrm{kms}$. & $\mathrm{DO}_{6}$ & -.38 & -10.20 \\
\hline $\mathrm{N}=$ & 570 & $\mathrm{R}^{2}=$ & .2562 \\
\hline
\end{tabular}

\section{Copyrights}

Copyright for this articleis retained by the author(s), with first publication rights granted to the journal.

This is an open-access article distributed under the terms and conditions of the CreativeCommons Attribution license (http://creativecommons.org/licenses/by/3.0/). 